Egyptian Journal of Aquatic Biology \& Fisheries

Zoology Department, Faculty of Science,

Ain Shams University, Cairo, Egypt.

ISSN $1110-6131$

Vol. 25(5): 1063 - 1091 (2021)

www.ejabf.journals.ekb.eg

\title{
Fish Skin Mucus as Putative Bio-resource for the Development of Next Generation Antibiotics
}

\author{
Anita Bhatnagar* and Pragati Rathi \\ Department of Zoology, Kurukshetra University, Kurukshetra, India \\ * Corresponding Author: anitabhatnagar@gmail.com
}

\begin{abstract}
ARTICLE INFO
Article History:

Received: April 22, 2021

Accepted: Oct. 29, 2021

Online: Nov. 30, 2021

Keywords:

Antibacterial effect,

Antibiotic resistance,

Fish epidermal mucus,

Novel antibiotics,

Zoo therapy

\section{ABSTRACT}

To resolve the ubiquitous crisis of antibiotic resistance rose due to overuse/misuse of certain drugs and antibiotics against which pathogenic bacteria have developed resistance; there is a need to replace these antibiotics with next-generation antibiotics and Zoo therapy is one of the important measures to attain this goal. In the context of reducing antibiotic resistance, fish epidermal mucus has been proven to be a boon to overcome this alarming issue. It holds valuable antimicrobial components in the form of antimicrobial peptides, glycoproteins, and antimicrobial bacteria which assist fishes to guard themselves against pathogens in the aquatic ecosystem. This study emphasizes the composition and role of fish skin mucus in disease resistance and describes the significance of antipathogenic bacteria isolated from skin mucus in protecting fish from various infections thus suggesting the means to replace antibiotics with next-generation drugs obtained from fish skin mucus taking a step towards sustainability of the ecosystem.
\end{abstract}

\section{INTRODUCTION}

The resistance of bacterial infections to current antibiotics continues rising. The World Health Organization has warned that this issue will become more serious. A recent study anticipates that by 2050 drug-resistant infections will affect more people than cancer. Thus, it is highly required to discover an alternative antimicrobial agent, especially in the current situation where most infectious disease pathogens are developing their resistance to the conventional drugs. Hence, it is critically important to find the next generation of antibiotics. Perhaps surprisingly, over 70 percent of currently used anti-infective are derived from naturally occurring chemicals. Plants and microbes produce a diverse array of complex chemicals, some of which have antibiotic or antiviral properties, or even are toxic to cells.

Consequently, there is an urgent need to produce more effective and safe antibiotics from animals as a therapy termed as Zoo therapy or animal therapy, and in this context, fishes occupy very important place. Fishes are not only the largest and diverse group of vertebrates, but also a major component of aquatic fauna and known for their benefits to human in many ways. Besides being a good and healthy food source, several compounds from fishes have been extracted and employed as remedies (Hamada et al., 1995). According to Eraldo Mand CostaNeto (2005), 'a total of 66 raw materials including scales, spur, shell, fat, skin, globe of the eye, tentacles and otolith are used in the elaboration of remedies to treat locally diagnosed ailments 
were identified. These remedies are administered to the patients in the form of plasters, teas, smokes and food. Asthma, bronchitis, stroke and wounds are the most usual illnesses treated by these animal-based medicines. However, the use of all these materials comes under the category of invasive method of using fish as animal therapy for humans.

It is also known that fishes live in challenging aquatic environments and are likely to support microbes that help them resist infections. The aquaculture industries with high densities of fishes are susceptible to diseases caused by infectious pathogens. Fish possess innumerable, well defined and complex defense mechanisms to protect themselves from these pathogenic infections amongst which fish skin mucus acts as the first line of physical defense against pathogens (Wang et al., 2011). A layer of mucus covers the external body surface contributing in important biological functions and defense system of fish. It can be defined as a viscous colloid containing the antibacterial enzymes, proteins and water known as mucins. Epidermal mucus facilitates fish survival due to its multifunctional barrier with various cellular and humoral components, especially to combat invading pathogens. It serves as an important component of innate immune mechanism in two ways. Firstly, it prevents the adherence of pathogens and sturdy colonization of potential infectious microbes and invasion of parasites by continuously producing the mucus and being regularly sloughed off (Arasu et al., 2013). Secondly, it contains a number of factors of innate immunity, such as proteins and enzymes including lysozyme, immunoglobulin, complement proteins, lectins, C-reactive protein (CRP), proteolytic enzymes, transferrins, alkaline phosphatase and various other antibacterial proteins and peptides (Arockiaraj et al., 2013; Arasu et al., 2013).

The aquatic environment is rich in pathogenic organisms, and the aquatic fishes are highly prone to the invasion of these pathogens (Dash et al., 2008). Therefore, the skin mucus in fish plays a significant role because it provides the first line of defense and is continuous with the linings of all body openings covering the fins. The fish cutaneous mucus plays crucial roles, including disease resistance, protection, as well as respiration, ionic and osmotic regulation, reproduction, excretion, communication, feeding and nest building (Ingram, 1980). The antimicrobial agents present in fish skin mucus provide first line of defense against invading pathogens (Subramanian et al., 2008). It acts as innate defense barrier of fish skin which is continuously replaced and helps to prevent stable colonization of the majority of infectious microbes such as bacteria and fungus found on fish body (Vennila et al., 2011). The external mucous gel forms a layer of adherent mucus covering the living epithelial cells forming a thin barrier that separates the fish from its aquatic environment.

The epidermal mucus is produced by goblet, club and sacciform cells found in fish epithelium (Shephard, 1994; Cone, 2009). Mucus secreting globlet cells are abundant on all fish epidermal surfaces and particularly on gill surfaces. Those cells produce mucus granules which burst to release their contents. Goblet cells contain sialylated, sulfated or neutral glycoproteins (Shephard, 1993).

Other secretory cells have also been identified whose secretions blend with the goblet cell secretions to give rise to mucus. These include sacciform cells and acidophilic granular cells (orserous goblet cells), whereas the latter produce basic proteins rather than glycoproteins (Zaccone et al., 2001). The club cell secretions have larger protein and lesser carbohydrate components (Zaccone et al., 2001).

The skin mucosa of fish is a crucial barrier and serves as a shield against the surrounding environment with biotic and abiotic factors. The mucosa consists of a cellular and a humoral part. The cellular part consists of the mucous membrane and its underlying connective tissue and 
humoral part contains the extracellular molecules present in the skin mucus (Salinas $\boldsymbol{e t}$ al., 2011). The skin mucosa of fish has different components such as proteins, carbohydrates, lipids, metabolites (Zaccone et al., 2001).

Thus, some of the components of this skin mucus can be a potential source of developing animal- based antibiotics for human pathogens that too via a noninvasive method. The characteristics, development/production of fish mucus, composition, its antimicrobial components and methods of studying and isolation of fish skin mucus have been described and reviewed in this chapter.

\section{FUNCTIONS OF MAJOR BIO-ACTIVE MOLECULES OF SKIN MUCUS}

The skin mucosal immune system is composed of innate and adaptive immune cells and molecules that function together to defend the host from invading pathogens (Guardiola $\boldsymbol{e t}$ al., 2016). The detailed information regarding roles of major components of fish skin mucus is given below:

a. Proteases- Proteases form a group of enzymes which hydrolyze the peptide bonds present in proteins by their catalytic action. Proteases in fish epidermal mucus play a noteworthy role in the innate immune mechanisms (Ingram, 1980). They are responsible of mortifying the pathogens and other foreign substances. Depending upon the chemical groups responsible for catalysis, the proteases are broadly classified into four categories; namely, serine proteases, cysteine proteases, aspartic proteases and metalloproteases (Hartley, 1960). Serine protease is described as one of the major mucus protease in several fish species, such as Cirrhinus mrigala, Labeo rohita, Catla catla, Rita rita and Channa punctata, and it comprises more than $25 \%$ of the complement system (Nonaka \& Miyazawa, 2001; Nigam et al., 2012). Proteases, such as trypsin (serine protease), cathepsin B and L (cysteine proteases), cathepsin D (aspartic protease) and metalloproteases have been identified in fish mucus of rainbow trout, coho and Atlantic salmon, Japanese eel (Aranishi \& Nakane, 1997; Subramanian et al., 2007). Proteases in skin mucus were reported for their key role in the natural resistance of fish against pathogens (Ingram, 1980) by directly acting on a pathogen or may indirectly prevent pathogen invasion by changing mucus texture to enhance the sloughing of mucus and detaching pathogens from the body surface (Aranishi et al., 1998).

Nigam et al. (2012) reported high protease activity in $C$. punctata and $C$. mrigala and low activity in L. rohita and C. catla. The protease activity of epidermal mucus of $L$. rohita was assessed to be the highest amongst the three Indian major carp species, including C. mrigala, C. catla and L. rohita (Dash et al., 2014). Al- rasheed et al. (2020) observed high activity of protease indicating a potential role in the prevention of colonization by pathogenic organisms on the skin of climbing perch.

b. Lectins- Lectins are any protein containing a non-catalytic carbohydrate-recognition domain (CRD). The terms agglutinin, phytoagglutinin, hemagglutinin and lectin are interchangeably used to manifest the naturally existing proteins/glycoproteins with multiple binding sites capable of agglutinating cells or precipitating glycoconjugates (Denis et al., 2003). One of the chief events in innate immune defense involves the pattern-based recognition of microbial targets as "non- self" by host lectins and related proteins and their subsequent destruction by complement and/or phagocytic cells (Matsushita et al., 2004). Different types of lectins have been reported in epidermal 
mucus of fishes. Tsutsui et al. (2011) addressed the presence of a new type of skin mucus lectin in catfish, Silurus asotus, displaying $\mathrm{Ca}^{+2}$ dependent mannose binding activity. A mannose binding lectin (MBL) that binds to pathogens was detected in Atlantic cod mucus (Rajan et al., 2011). Galectins of different forms were also demonstrated to have antibacterial activity (Stowell et al., 2014; Cha et al., 2015). Nattectin, a C-type lectin binding to galactose, was also reported in Atlantic salmon affected by amoebic gill disease (Valdenegro-Vega $\boldsymbol{e t}$ al., 2014). Fructose binding lectin has been observed in sea bass skin mucus (Cordero et al., 2015). Carbohydrates which are specific to this type of lectins are galactose, lactose, fucose, melibiose and rhamnose (Takashima \& Hibiya, 1995). Tsutsui et al. (2009) purified a lactose-specific lectin (pentraxin) of molecular mass $25 \mathrm{kDa}$ from the skin mucus of a cartilaginous fish, Raja kenojei. Those studies reflect the active participation of lectins in the self-defense system by acting on the external body surface. Notably, activation of the complement pathway takes place when lectins interact with pathogenic bacteria present on the fish surface (Matsushita et al., 2004). Easy and Ross (2009) observed an increase in the lectin levels of cutaneous mucus during parasitic infection.

c. Antimicrobial peptides- Antimicrobial peptides belong to a larger group of naturally occurring short polypeptides and share similar amphipathic $\alpha$-helical structures that can interact strongly and penetrate phospholipid membranes (Rakers et al., 2013). Antimicrobial peptides are increasingly recognized as condemning factors in host defense mechanism and are found in organisms ranging from microbes, plants to animal species (Fernandes et al., 2004; Kennedy et al., 2009). Fishes are a great source of these AMPs and express all of the major classes of peptides, such as defensins, cathelicidins, hepcidins and histone-derived peptides (Valero et al., 2013). Antimicrobial peptides are secreted by immune cells and released into mucus i.e. piscidin, epinecidin-1 and chrysophsins (Fekih-Zaghbib et al., 2013). Antimicrobial peptides are generally defined as broad spectrum cationic molecule having low molecular weight peptides (size $<10$ $\mathrm{kDa}$; length 12-50 amino acids) with a net positive charge because of the presence of excess basic lysine and arginine residues over acidic residues. They fold, owing to the presence of disulphide bridges or contact with membranes, into three dimensional amphiphilic structures. The benefit of the AMPs is that they can function without either high specificity or memory. These are synthesized at low metabolic costs, capable of mass storage and readily available after infection. Such molecules are well suited for interacting with bacterial membranes having negatively charged and hydrophilic head groups and hydrophobic cores. Antimicrobial peptides adopt several mechanisms for their activities: some appears to be associated on the membrane surface and displace the outer bilayer (Shai, 2002), while others have shown to span the bilayer and associate to form the channel depolarizing the target cells. They play an important role in fishes in comparison to mammalian fauna because fish rely more on their innate immune system (Hancock \& Scott, 2000). Lee et al. (2007) determined the solution structure of piscidin1 , and then, piscidin-2 was found to cause cell membrane damage to three fungal strains known to cause infections in humans (Sung et al., 2008). Su (2011) analyzed the antibacterial activity of skin mucus of yellow catfish Pelteobagrus fulvidraco. A novel linear antimicrobial peptide Pelteobagris purified from skin mucus was found to exhibit antibacterial activity against gram positive and gram negative bacteria as well as fungi. 
The fish peptides exhibit broad-spectrum antimicrobial activity by killing both fish and human pathogens (Das et al., 2013).

d. Lysozyme- Lysozyme being a chief constituent of the innate immune system ensures protection against pathogenic invasion (Dash et al., 2011). It is a mucolytic enzyme of leucocytic origin. The common feature of lysozyme is their ability to hydrolyse $\beta-(1,4)$ glycosidic bonds between the alternating $\mathrm{N}$-acetylmuramic acid (NAM) and N-acetyl glucosamine (NAG) residues of peptidoglycan of bacterial cell wall resulting in rapid cell lysis in a hypo-osmotic environment. Broadly, lysozymes are classified into five major types, such as (i) chicken-type lysozyme (c-type) that includes stomach lysozyme and $\mathrm{Ca}^{+2}$ binding lysozyme, (ii) goose-type lysozyme (g-type), (iii) plant-type lysozyme, (iv) bacterial lysozyme, and (v) T4 phage lysozyme (phage-type). However, in fishes only c- and g-type lysozymes have been reported (Beintema \& Terwisscha van Scheltinga, 1996; Qasba \& Kumar, 1997). The lysozyme response has been found variable in its potency depending on the species and the tissue location (Qasba \& Kumar, 1997). The estimation of lysozyme may be of diagnostic value to determine the disease status of fish. Lysozyme has been reported to inhibit viruses (Lee-Huang et al., 1999), parasites (Leon-Sicairos et al., 2006) and fungi (Wu et al., 1999) despite the absence of typical peptidoglycan in their envelopes. Alkaline phosphatase (AP) is remarkably a lysosomal enzyme suggested to have a protective role in fish during the first stages of wound healing (Iger \& Abraham, 1994). Moreover, the enzyme attacks structures containing muramic acid, hydrolyses glycol chitin and has a restricted degrading effect on chitin, which is a major component of the cell walls of fungi and the exoskeletons of certain invertebrates (Wu et al., 1999). Fast et al. (2002) noted an increase in mucus lysozyme activity and alkaline phosphatase activity in Rainbow trout and Atlantic salmon when infected with sea lice in the earlier days of infection that decreased further. A large increase was detected in the production of alkaline phosphatase in pavement and mucous cells in the epidermis of carp following wounding. It is worthy to mention that, skin mucus AP is responsive to biotic and abiotic factors, including nutrients and bioactive feed components, prebiotics and probiotics (Lallès, 2019). Additionally, Lysozyme induces phagocytosis directly by activating polymorphonuclear leucocytes and macrophages, or indirectly by an opsoninic effect. Lysozymes found in epidermal mucus are vital constituents in protection opposing several bacterial, viral as well as parasitic infections (Abbas et al., 2020; Ghalambor $\boldsymbol{e t}$ al., 2020).

e. C-reactive proteins- CRPs belong to a family of multifunctional proteins (pentraxins), and they are capable of binding various ligands in a $\mathrm{Ca}^{2+}$ dependent binding affinity. They are characterized by their cyclic pentameric structure and high sequence similarity (Gewurz et al., 1995). The main ligand for CRP includes the phosphoryl choline moiety of pneumococcal C-polysachcharides (CPS) and phospholipids. C-reactive proteins take part in innate immune defense through activation of the complement pathways and play an important role in the recognition and clearance of apoptotic cells (Nauta et al., 2003). It can also act as opsonin and can cause the precipitation and agglutination of macromolecules or microorganisms with surface phophorylcholine. At the commencement of various diseases, the quantity of a blood protein component, Creactive protein (CRP), increases seemingly in response to the inflammation and tissue necrosis that leads to pathologic conditions and closely corresponds their course. Ramos 
and Smith (1978) conducted a study to evaluate CRP level in the epidermal mucus of Tilapia mossambica after injury. The CRP level was measured before and after injury, and maximum value of CRP was observed at the end of $24 \mathrm{hr}$ and $48 \mathrm{hr}$ intervals. Thus, those proteins proved to help enhancing the immunity of fish against several pathogens.

f. Alkaline phosphatase- A lysosomal enzyme which is a vital component of epidermal mucus of fish was regarded as an antimicrobial constituent because of its hydrolytic property (Dash et al., 2011; Dash et al., 2014; Guardiola et al., 2014). Value of ALP increased in fish during skin regeneration, during the earliest stages of any type of abrasion healing, pathogenic infection and distress (Rai \& Mittal, 1983; Iger \& Abraham, 1990, 1997).

g. Complement system- Complement system is known to contain a category of protein and non-protein elements that contributes in both innate and adaptive immunity. It contains approximately thirty- five plasma and membrane-bound proteins; those conciliate a continuum of events for proteolytic reactions which results in elimination of invading microorganisms (Boshra et al., 2006). Important complement proteins, such as C3, C7 and $\mathrm{C} 1 \mathrm{q}$ have been reported in skin mucosa of Atlantic halibut (H. hippoglossus), grass carp (Ctenopharyngodon idella) and siberian sturgeon (Acipenser baerii), respectively (Magnadottir et al., 2005; Fan et al., 2015).

\section{METHODS TO ANALYZE FISH SKIN MUCUS}

Cutaneous secretion exudated from fish body- guards protects fish from pathogens by working as efficient barrier. Therefore, the purity or integrity of epidermal secretion is essential for the welfare, health and survival of the fish. Fish skin mucus is an important matrix to estimate distress, infection and starvation as the expelled molecules in the epidermal secretion can reflect fish health. The quality of fish cutaneous mucus, such as viscosity, colour, presence and amount of proteins, cortisol, lipids and enzymes excreted in the skin mucus is a possible indicator to assess the health of fish. Several methods have been employed to evaluate the contents of various bio-active molecules of fish skin mucus which are directly related to the well- being of fish. The alterations in the quality of important constituents are a critical factor to monitor the immunity of fish due to different types of challenges induced, including stress, feed deprivation and pollution. Various qualitative and quantitative methods used to analyze the fish cutaneous mucus for biochemical components to assess the well- being of healthy fish as well as stressed or challenged fish are explained below:

a. Estimation of Protein- Biochemical composition of fish skin mucus is a reliable biomarker of health status of fish. Following methods have been used for qualitative and quantitative estimations of protein.

\section{$>\quad$ Lowry assay (Lowry et al., 1951)}

This is a biochemical method used to determine total protein in any sample.

\section{Procedure:}

$5 \mathrm{ml}$ of Lowry reagent (50 parts of solution A and one part of solution B) is added to $1.0 \mathrm{ml}$ of diluted protein extract of epidermal mucus which is obtained by proteolytic enzyme assay of epidermal mucus, and then it is allowed to stand for $10 \mathrm{~min}$ at room temperature. Then, $0.5 \mathrm{ml}$ of Folin's reagent is added and mixed thoroughly. After $30 \mathrm{~min}$, a blue color develops. The optical density is measured at $660 \mathrm{~nm}$ using 
spectrophotometer. Distilled water is used as blank. The amount of protein is calculated by plotting a standard curve, and Bovine Serum Albumin (BSA) is taken as standard protein.

b. Estimation of Lipids-

$>$ Free fatty acid test: This test is performed to measure hydrolytic rancidity in oil or given sample. Hydrolytic rancidity is a chemical hydrolysis by enzymes of fats Procedure into free fatty acids and glycerol (Novak, 1965).

To estimate free fatty acids in epidermal mucus, $2.5 \mathrm{ml}$ of mucus sample is placed in test tube and 1 to 2 drops of phenolphthalein solution are poured in it. $0.1 \% \mathrm{NaOH}$ is diluted and slowly mixed to the solution until a faint but the appearance of a permanent pink color is sustained. Appearance of pink color confirms the presence of fatty acids in mucus.

c. Cortisol estimation- Cortisol levels in the fish skin mucus are measured using an ELISA kit.

To measure cortisol content in epidermal mucus, standard solutions and diluted samples are pipetted on a clear microtiter plate which is coated with an antibody to capture mouse antibodies. A cortisol-peroxidase conjugate is then added to the wells. The binding reaction is initiated by the addition of a monoclonal antibody to cortisol. The plates are incubated for $1 \mathrm{hr}$ and then washed to add the substrate. The substrate reacts with the bound cortisol-peroxidase conjugate. After incubation of 10-15 min, the intensity of the generated color is measured in a microtiter plate reader at $450 \mathrm{~nm}$. The cortisol value is expressed as $\mathrm{mg}$ cortisol $\mathrm{mL}^{-1}$ of epidermal mucus.

d. Carbohydrate estimation-

$>$ Anthrone test (Trevelyan et al., 1952)

$2 \mathrm{ml}$ of anthrone reagent is poured into clean test tubes. Few drops of fish epidermal mucus is added into the test tubes and mixed. The mixture is allowed to stand for 10 minutes. Appearance of pink color confirms the presence of carbohydrates in the sample. For standard curve; distilled water is used as blank. The absorbance is taken at $620 \mathrm{~nm}$ against blank.

Apart from this, techniques have been used to isolate and identify different types of proteins and measure their content to demonstrate the quality of fish skin mucus according to various physiological and behavioral conditions of fishes. For example, Bergsson et al. (2005) isolated four cationic proteins from the mucus extract by using weak cationic exchange chromatography combined with reversed-phase chromatography. Using N-terminal and Cterminal amino acid sequence analysis, in collaboration with mass spectroscopy, the antimicrobial proteins were identified as histone $\mathrm{H} 2 \mathrm{~B}(13.5 \mathrm{KDa})$, ribosomal protein L40 (6.4 $\mathrm{KDa})$, ribosomal protein L36A $(12.3 \mathrm{KDa})$ and ribosomal protein L35 (14.2 KDa). It was observed that, the presence of the above- mentioned proteins in the fish epidermal secretion is directly correlated with the antibacterial activity of epidermal secretion of Atlantic cod, Gadus morhua.

Similarly, GC-MS (Gas chromatography - mass spectrometry) has been used to identify and isolate skin mucus constituents. GC-MS instrument is used to segregate chemical mixtures which are gas chromatography components and identify the mass spectrometry components at molecular level. The important consideration of GC-MS states that, when a mixture is heated at a certain temperature, it segregates into its individual constituents and gases, which are generated 
upon heating the mixture, are carried via a column containing an inert gas most commonly Helium. Constituents, thus segregated, appear from the column opening and flow into the MS where these are identified by calculating the mass of analyte molecule.

\section{Procedure of GC-MS (Message, 1984)}

At the commencement of experiment, $1 \mu \mathrm{l}$ of sample is introduced in GC-MS equipped with a split injector and a PE Auto system XL gas chromatograph, interfaced with a Turbo-mass spectrometric mass selective detector system. The MS is operated in the electron ionization mode $(70 \mathrm{eV})$. The flow rate of Inert gas Helium is adjusted to $1.2 \mathrm{ml} \mathrm{min}^{-1}$. Column head pressure is adjusted to $196.6 \mathrm{kPa}$ after connecting the analytical column to the main system. Initially, the temperature is set at $50^{\circ} \mathrm{C}$ for 1 minute, then it is elevated to $170^{\circ} \mathrm{C}$, first at the rate of $25^{\circ} \mathrm{C} /$ minute held up to $150^{\circ} \mathrm{C}$, followed by a rise of $5^{\circ} \mathrm{C} /$ minute to $170^{\circ} \mathrm{C}$ without hold. The final temperature is held for $6 \mathrm{~min}$. The MS is operated in an ACQ mode scanning from $\mathrm{m} / \mathrm{z} 40$ to 600.0 .

GC-MS analysis of both healthy and pathogen challenged fish skin mucus of Heteropneustis fossilis, Clarias batrachus, L. rohita, Ctenopharyngodon idella, Cirrhinus mrigala, Cyprinus carpio and Hypophthalmichthys nobilis has been carried out by Kumari (2018) to identify various components of skin mucus. The chromatograms for various components were studied by calculating the peaks exhibited by both healthy and challenged skin mucus of fish species. Furthermore, a total number of 258 and 284 compounds, belonging to different classes, such as amino acid and derivatives, fatty acids and derivatives, metabolites and their derivatives, azatidine and derivatives, alkane, alkene, hydroxy, secondary alcohols, diketones, hydrocarbons esters and ketones aromatic compounds, phenol and derivates and many other compounds were detected in healthy fish mucus and challenged fish mucus extracts, respectively.

Quantitative analysis- Several studies have been conducted to monitor the health and immunity of fish by quantitative measurements of skin mucosal parameters, including abundance of mucus cells on the surface of fish.

Analysis of abundance of mucus cells (Kiernan, 2008)- Glycoproteins are important constituents of fish skin mucus that have their origin in the diet. Hence, it was hypothesized that starvation can potentially change the abundance and glucidic nature of skin mucus cells, and subsequently switching the mucus characteristics. Landeira-Dabarca et al. (2014) conducted an experiment to examine the abundance of mucus cells and their glucidic nature of Atlantic salmon, Salmo salar L. by giving food deprivation treatment for 18 days. That fish diet method was described in the study of Kiernan (2008). Histological analysis was performed by resecting the skin samples from 3 different zones of fish body; head region (area between head and dorsal fin insertion), lateral region (area between dorsal and ventral fin insertion) and ventral region (area between vental fin insertion and anus). Standard staining methods of Kiernan (2008) were followed to distinguish the mucus cells based on their glucidic content. Results were compared with the controlled group which were fed daily with automated feeding device. Major outcomes of this study revealed significant reduction in the abundance of mucus cells in the lateral region of food deprived fish compared to feeding fish after seven days of food deprivation. The proportion of acidic glycoconjugates was also found to be higher in the unfed fish as compared to the fed fish. 


\section{BIOLOGICAL ROLES OF FISH SKIN MUCUS}

The components of mucus gel matrix such as proteins, immune related components, antimicrobial components as well as diverse community of mucus dwelling micro-organisms play various biological roles in maintaining homeostasis and fish health. Fish skin mucus, acting as primary barrier against the various kinds of infections, block the entry of pathogens by exhibiting antibacterial activity, thus enhancing the immune response of fish.

Epidermal mucosal components performing the biological roles (Fig. 1) for the well- being of fish are explained below-

a) Antimicrobial components- Fish cutaneous mucus displays a wide range of functions in promoting immune response of fish due to the presence of a variety of antimicrobial components, such as pore forming glycoproteins, enzymes and proteins. Easy and Ross (2009) studied the changes in protein profile of Atlantic salmon (Salmo salar) skin mucus following sea lice (Lepeophtheirus salmonis) infection. To examine changes in protein profiles, two- dimensional gel electrophoresis was performed on fish cutaneous mucus; mucus samples from the controlled and challenged fish were taken as treatments. Results revealed clear differences in lectin, actin and transferrin protein profiles in mucus of challenged fish. A cluster of acidic proteins of approximately $80 \mathrm{kDa}$ at $\mathrm{pH} 4-5$ was found in challenged fish that were barely present or completely absent in healthy fish.

On the other hand, high chitinase activity may be responsible for the strong antibacterial, antifungal and antiproliferative properties of skin mucus of Dasyatis pastinaca (Fuochi et al., 2017). Western blot analysis was done to observe the CHIT 1 expression in skin mucus of $D$. pastinaca against gram negative bacteria. The results revealed high chitinase activity of fish skin mucus against Gram negative bacteria, Klebsiella pneumonia, E. coli and Pseudomonas aeruginosa contributing to the antibacterial activity of fish epidermal mucus. Similarly, other skin mucus components or metabolites, such as glucose, cortisol and lactate are the potential biomarkers responding to various physiological challenges contribute to evaluate animal health by studying the epidermal secretion composition of teleost marine species (Fernández-Alacid et al., 2018). The modification of epidermal secretion as well as composition provides an effective strategy for conquering physiological stresses in fish. Three marine species i.e. meagre (Argyrosomus regius), European sea bass (Dicentrarchus labrax) and gilthead sea bream (Sparus aurata) were selected and exposed to three different physiological challenges ie. simulated capture process, infection with Vibrio anguillarum $\left(5 \times 10^{4} \mathrm{CFU}\right.$ per fish) and fasting respectively and production of mucus, concentration of glucose, cortisol, proteins and lactate were examined to assess how these mucus metabolites responded to the various stresses. Results showed an increase in the glucose/protein ratio, which reflected acute stress through a large exudation of glucose in the fish skin mucus and mucus response in the face of a pathogenic infection provoking more mucus exudation with a loss of soluble protein. This, in turn, indicates the presence of changes in protein turnover preferences to cope with the challenge. Thus, the metabolite profile of fish skin mucus proved to help in measuring stress responses towards different environmental challenges. 


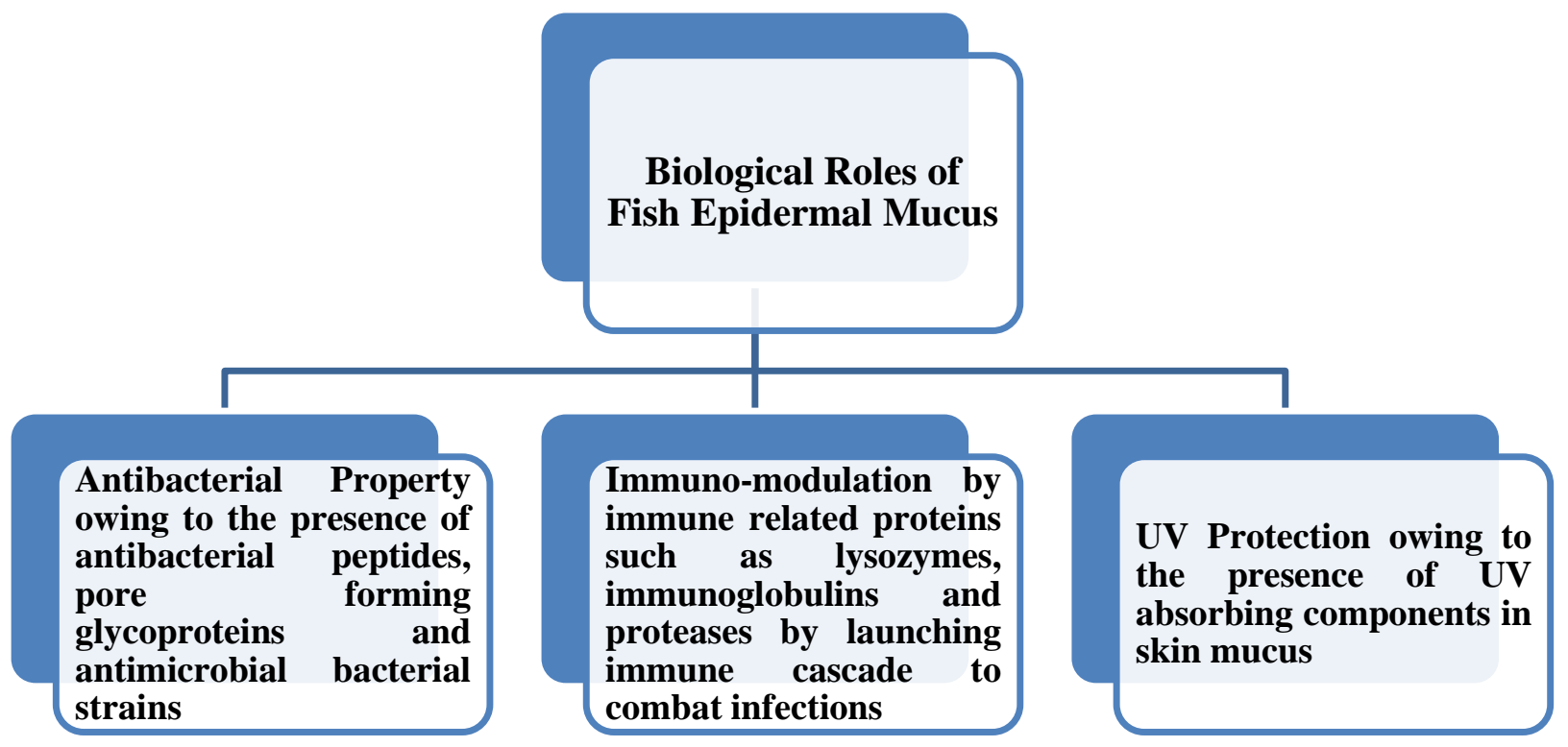

Fig. 1. Biological roles of fish epidermal mucus

b) Immune related components- Active mucosal immune system is a prime characteristic of bony fishes. The external mucosa-associated lymphoid tissues (MALT) found in fish include skin-associated lymphoid tissue (SALT), the gill-associated lymphoid tissue (GIALT) and the nasopharynx-associated lymphoid tissue (NALT) (Salinas, 2015). The main cellular components of fish innate immunity observed in mucosal surfaces are leukocytes, mast/ eosinophilic granule cells (EGCs), mucosal dendritic cells (DSs), macrophages and granulocytes (Gomez et al., 2013). Fish mucus is also enriched with a multitude of immune-related proteins, such as lysozymes, phosphatases, esterases, proteolytic enzymes, complement factors, lectins, immunoglobulins, and C-reactive proteins that attempt to eliminate pathogens and launch the immune cascade when an infection occurs. Guardiola et al. (2014) identified and characterized different constitutive humoral defense mechanisms of the skin mucus of gilthead seabream (Sparus aurata) for the first time. Studies were conducted to estimate the levels of total immunoglobulin $\mathrm{M}$, several enzymes and proteins (peroxidase, lysozyme, alkaline phosphatase, esterases, proteases and antiproteases), as well as the bactericidal activity against opportunist fish pathogens (Vibrio harveyi, $V$. angillarum, Photobacterium damselae) and non-pathogenic bacteria (Escherichia coli, Bacillus subtilis) in the skin mucus and compared to those found in the serum. Results revealed that, gilthead seabream skin mucus contains lower levels of IgM, similar levels of lysozyme, alkaline phosphatase and proteases, and higher esterase, peroxidase and antiprotease activities than serum.

Raj et al. (2011) reported the role of fish skin mucus as an innate immune protection system against viral epidermal entry, and it was demonstrated that skin mucus removal and epidermal lesions enhance CyHV-3 entry in carp. Important lysosomal enzymes, such as acid and alkaline phosphatases, which are associated with the innate immune defense mechanism in fishes, have also been identified in fish skin mucus (Nigam et al., 2012). Thus, it was deduced that, fish skin mucus prevents the 
colonization of harmful pathogenic bacteria on the surface of fish thus blocking their entry in fish body.

c) UV protection- UV radiations ((UV, 280 to $400 \mathrm{~nm}$ ) pose damage to the fishes living in shallow water (Lesser et al. 2001, Zagarese \& Williamson, 2001). UV-absorbing compounds have been found in the skin mucus of shallow-dwelling marine fishes which protect them from harmful effects of UV rays (Zamzow \& Losey, 2002; Zamzow 2003, 2004). Zamzow (2004) reported that fishes lacking UV absorbing compounds in the diet tend to suffer higher rates of skin damage when exposed to solar UV. Zamzow and Losey (2002) suggested the occurrence of UV-absorbing compounds in the skin mucus of herbivorous, omnivorous and carnivorous fishes.

\section{ECOLOGICAL ROLES OF FISH SKIN MUCUS}

Fish epidermal mucus plays crucial roles in ecological functions such as in intraspecific as well as interspecific communication (Fig. 2).

I. Intraspecific communication- Hepper (1991) and Pfennig and Sherman (1995) reported that, kinship and familiarity perform crucial functions in incorporating communal connections, such as territoriality, courtship, supremacy hierarchies and group living. Chemical signs are predominant factors of group living and individuals of same species are acknowledged on the basis of distinctive chemical alerts. Chemical cues from fish mucus aid in transmitting signals among individuals of the same species or conspecifics either as attracting or alluring signs, permitting the location of favourable domain or partners. They may also act as alert signals essential for warning individuals to potent risk or danger. Some very important intraspecific communication traits are described below-

a) Fish shoaling - Signals produced in the form of chemicals from epidermal secretion of siblings are essential in fish shoaling (Baker \& Hicks, 2003). Phosphatidylcholines observed in epidermal secretion has been found to generate school forming in young catfish (Plosotus lineatus) (Matsumura et al., 2004). In this study, for the behavioural assay or the turn behavior towards conspecifics, solidified agar slabs or blocks containing fish mucus of conspecifics and urethane sponge containing the school mate seawater were prepared. The results of behavioural bioassay indicate that, solidified agar slabs or blocks coated by fish mucus evoked the turn behavior in fishes. The fish showed more turn activity towards the mucus than towards seawater. To illustrate the turn behavior towards fish mucus, a school recognition substance (SRS) was characterized which was extracted from fish skin mucus using HPLC. Results by analysis of NMR and mass spectral data after extracting and fractionating, the SRS revealed that possible SRS was shown to be phosphatidylcholine (PC), which induced the school forming behavior in the young catfish. 


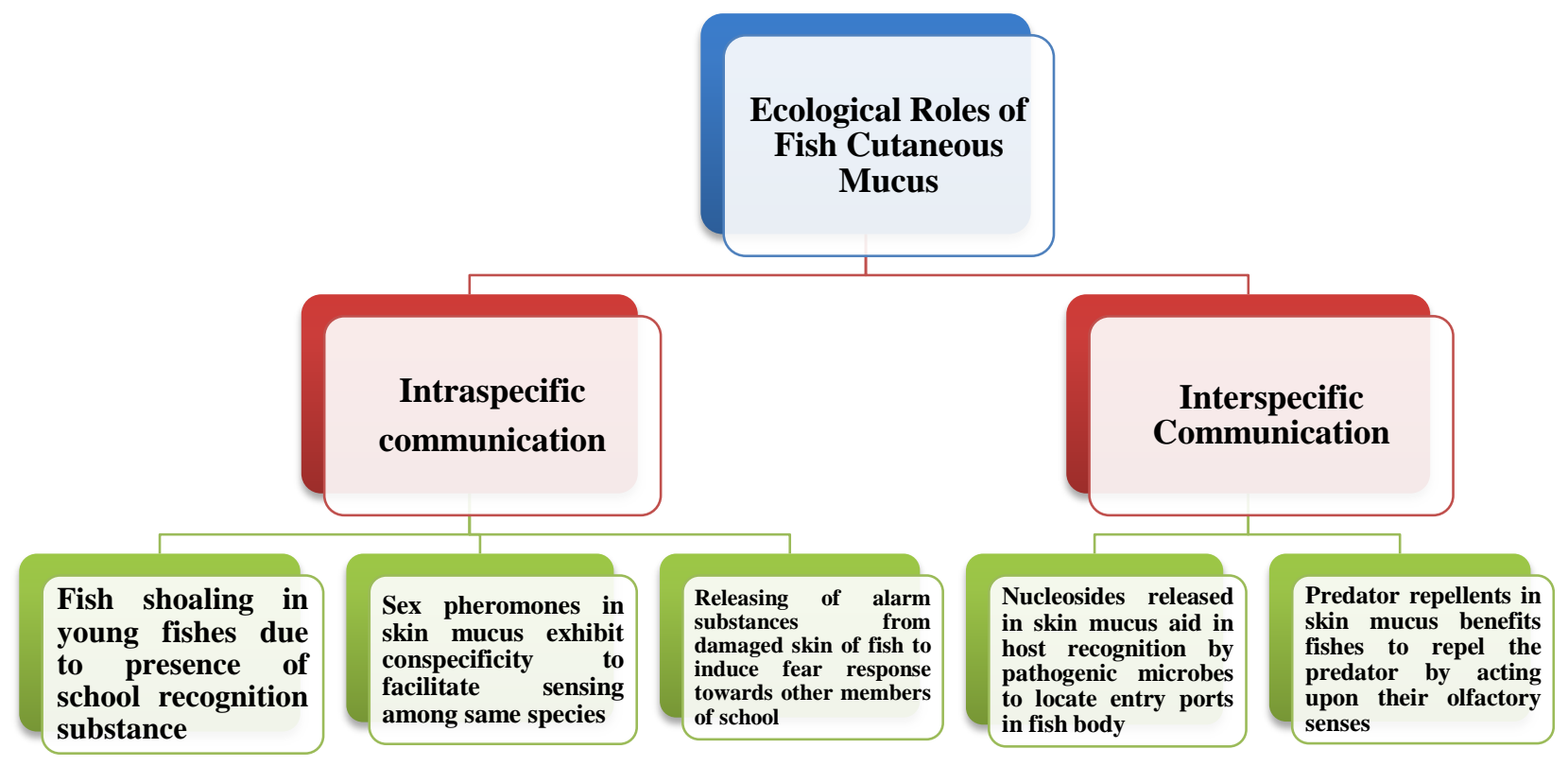

Fig. 2. Ecological roles of fish epidermal mucus

b) Reproduction- Chemical communication has been shown to be vital in many aspects of teleost biology, particularly reproduction (Stacey \& Sorensen, 2002). Chemical communication may play a role in the reproduction of the European eel (Huertas et al., 2006). Another possible source of chemical cues or odorants in reproductive biology of fish is the skin mucus (Stabell \& Selset, 1980). Huertas et al. (2007) reported that Conspecific bile and skin mucus are sources of potent odorants for the European eel. Furthermore, both the quantity and the quality of some of the odorants present depend on the sex and state of sexual maturation of the donor. Both the bile and the mucus are therefore sources of potential sex pheromones in the European eel. Some studies found several attractants in fish skin mucus which represent the conspecificity; these attractants are only sensed by the member of the same species which produce them (Wisenden \& Barbour, 2005). Tetrodotoxin (TTX), which has also been found in fish mucus, is also known to act as a sex pheromone that attracts males towards fertile females (Matsumura, 1995; Itoi et al., 2014).

c) Alarm signaling- To sustain and survive in natural environment, detection and avoidance of predators is an essential phenomenon. The release of alarm signals after injury is a widely reported mechanism in fish that produces an alarm response in conspecifics with the ultimate objective of avoiding the source of danger (Smith, 1992). In many fishes, skin damage elicits the discharge of chemicals that cause escape and fear in members of the shoal (Pfeiffer, 1977).

Mathuru et al. (2012) assessed that Schreckstoff, the alarm substance, is a mixture that includes the glycosaminoglycan (GAG) chondroitin and purified chondroitins trigger fear responses. Exposure to purified chondroitin in zebrafish elicited alarm behavior which further led to slow swimming and bottom dwelling.

II. Interspecific communication- Cutaneous secretion of fishes is an important component in interspecific interactions which includes mutualism, ammensalism, predation and symbiotic associations. 
a) Microbial chemotaxis- A wide range of organisms can detect cutaneous secretion and generate different kinds of responses. Chemotactic motility is an essential parameter for the virulence of Vibrio anguillarum in waterborne infections of fish. Larsen et al. (2001) studied the chemotactic motility of Vibrio anguillarum towards the skin, gill and intestinal mucus of rainbow trout and capillary tube method of chemotaxis. That study confirmed that $V$. anguillarum was significantly more chemotactic to skin and intestinal mucus than gill mucus, suggesting the preference for port of entrance in the fish.

Bader et al. (2003) observed $F$. columnare cells attached to the skin and gill mucus, in just 5 min after a dip immersion, by using a specific PCR which revealed that $F$. columnare rapidly seen on cutaneous tissue is important in the columnaris disease which causes epidermal lesions on fish body after infection. Chemodetection of cutaneous secretion by the pathogens, and change in behavior had been observed in oligochaetes, myxozoans and ectoparasites like copepods (Ohashi et al., 2007; Klesius et al., 2008; Kallert et al., 2011).

Nucleosides are known as suitable prompts for rapid host recognition by the waterborne parasite stages due to their continuous discharge into surface mucus. Kallert et al. (2011) studied the chemical recognition trait which enables a parasitic life cycle in aquatic habitats and free nucleosides (inosine, 20-deoxyinosine and guanosine) exudating in trout skin mucus were found to cause myxozoan attachment. Abdullah and Saad (2015) reported that the lack of $\mathrm{N}$-acetylneuraminic acid (Neu5Ac) in epidermal secretion of clownfish defends it from the bite of anemone, Hetractis magnifica, which releases its poison under the stimulus of Neu5Ac near itself.

b) Predator repulsion- Surfactant toxins are important constituents in skin mucus of various fish species, and can be regarded as defense secretions having both hemolytic and ichthyotoxic activities.

Skin mucus constituents of fish play crucial roles in predator-prey relationships, either as predator repellents or as warning signs for both predators and prey. Tachibana et al. (1984) conducted an experiment to segregate a sequence of ichthyotoxic and hemolytic steroid aminoglycosides, pavoninins 1 to 6 from the cutaneous defensive secretion of the sole Pardachirus pavoninus, and their defined chemical structures have been evaluated by spectroscopic studies and chemical conversions. The results revealed the pavoninins present in skin mucus elicited repellent response against sharks. The study also reflected on the pardaxin (antimicrobial peptide), pavoninins, and mosesins (monoglycosidic cholestanoids) secreted in skin mucus by several species of soles and explained their property of generating repellent response in sharks by acting upon their olfactory senses in order to keep them away (Tachibana et al., 1984). The Red Sea Moses sole, Pardachirus marmoratus, is also known to repel sharks by releasing venomous discharge as soon as sharks try to prey upon this (Clark, 1974). Tetradotoxin (TTX) is a potent neurotoxin and serves as an antipredator device for organisms that produce or accumulate it (Williams, 2010).

\section{ROLE OF INDIGENOUS SKIN BACTERIA OF FISH}

The aquaculture industry has greatly intensified productivity and is now a major economic activity in many countries (FAO, 2007). Massive production in fish farms may expose fish to stressful conditions which, in turn, has the potential to induce infection by opportunistic 
pathogens. Infections are usually prevented and controlled by intrusive veterinary medicines and antibiotics which sometimes lead to emergence of antibiotic resistant bacteria. Therefore, alternative strategies to prevent antibiotic resistance and opportunistic infections in aquaculture are strongly needed. The development of probiotics appears to be one of the most promising ways to achieve this goal as probiotics are live beneficial micro-organisms used as supplements to maintain the microbial balance and benefit the host by enhancing growth, immunity and improving water quality (Fuller, 1989; Merrifield $\boldsymbol{e t}$ al., 2010). They can be administered via feed and also by direct supplementation in the rearing water of fish.

The fish skin mucus is harbored by these beneficial bacterial communities which act as checkpoint for the pathogenic microbes. Several studies have been conducted which confirmed the presence of probiotic antimicrobial bacteria in fish skin mucus. Indigenous skin microbiota of lionfish was found to produce antimicrobial metabolites against fish pathogens (Stevens et al., 2016). Those metabolites have been used by host species to combat infections caused by pathogens (Harder et al., 2003, O'Brien \& Wright 2011). Chabrillón et al. (2005) reported that isolated micro-organisms from skin mucus of sole were able to prevent the colonization of Photobacterium damselae ssp. Piscicida, thus aiding in disease resistance. Similarly, Spanggaard et al. (2001) demonstrated the presence of pseudomonads in skin mucus of rainbow trout which prevented the proliferation of Vibrio anguillarum.

The indigenous skin mucus bacteria can be considered as a biological control measure for pathogenic microbes due to the fact that an effective vaccine is not available for various challenging diseases in aquaculture. Boutin et al. (2012) conducted an experiment to isolate the antimicrobial bacterial strains from skin mucus of brook charr. The afore- mentioned authors revealed that some bacterial isolates were able to inhibit Flavobacterium columnare and $F$. psychrophilum. In vivo analysis, a reduction was detected in mortality when these isolated probiotic bacterial strains were used to treat columnaris disease, subsequently making them a suitable alternative of antibiotics. Fuente et al. (2015) investigated antagonistic the effect of bacterial isolates in skin mucus of Chilean salmon against fish pathogens A. hydrophila, $V$. anguillarum and F. psychrophilum. Similarly, Lowrey et al. (2015) reported the highest bacterial diversity on skin mucus of Rainbow Trout (Oncorhynchus mykiss) followed by olfactory organ, gills and gut. Notably, in vitro assays were performed to confirm the antipathogenic effect of bacteria isolated from skin mucus and it was reported that two sp. of Arthrobacter, a Psychrobacter sp. strain and a combined skin aerobic bacterial strain were able to inhibit the growth of two aquatic fungal pathogens; namely, Saprolegnia australis and Mucor hiemalis. Takeuchi et al. (2021) investigated the bacterial strains in skin mucus of the rainbow trout by using 16S rRNA gene amplicon sequencing, and it was revealed that bacterial strains Bosea sp. OX14 and Flavobacterium sp. GL7 present in skin mucus were able to obstruct the growth of $F$. psychrophilum KU190628-78 and NCIMB $1947^{\mathrm{T}}$ by producing antagonistic compounds of < $3 \mathrm{kDa}$ in size. The antagonistic properties and vital functions (Table 1) of probiotic bacterial strains entangled in fish skin mucus make them a convenient candidate to be utilized as substitute of antibiotic drugs in fish welfare. 
Table 1. Role of indigenous microbial communities of fish skin mucus

\begin{tabular}{|c|c|c|c|}
\hline Sr. No. & Role & Mode of Action & Reference \\
\hline 1. & $\begin{array}{l}\text { Disease } \\
\text { Resistance }\end{array}$ & $\begin{array}{l}\text { Directly by inhibiting growth } \\
\text { of pathogens } \\
\text { Indirectly by preventing } \\
\text { colonization on the surface of } \\
\text { fish through the production of } \\
\text { inhibitory compounds }\end{array}$ & $\begin{array}{l}\text { O'Brien and Wright } \\
\text { (2011) }\end{array}$ \\
\hline 2. & Drag Reduction & $\begin{array}{l}\text { - Bacterial isolates from tuna } \\
\text { (Scomberomorus commerson) } \\
\text { played a role in fish } \\
\text { locomotion by smoothing the } \\
\text { surface, thereby minimizing } \\
\text { surface area and decreasing } \\
\text { frictional drag due to their } \\
\text { high colonial hydrophobicity. } \\
\text { * Bacterial isolates from the skin } \\
\text { mucus of cornetfish } \\
\text { (Fistularia commersonii } \\
\text { actively reduced drag in a } \\
\text { turbulent flow rheometer. }\end{array}$ & $\begin{array}{l}\text { Sar and Rosenberg } \\
(1989)\end{array}$ \\
\hline 3. & $\begin{array}{l}\text { Antibacterial } \\
\text { Activity }\end{array}$ & $\begin{array}{l}\text { * Inhibitory activity of } \\
\text { endogenous bacterial } \\
\text { communities isolated from } \\
\text { skin mucus of brook charr } \\
\text { Salvelinus fontinalis against } \\
\text { Flavobacterium columnare } \\
\text { and F.psychrophilum. } \\
\text { * Antibacterial activity of } \\
\text { bacteria isolated from skin } \\
\text { mucus of lionfish Pterois } \\
\text { volitans/ miles comples against } \\
\text { six known fish pathogens viz. } \\
\text { Vibrio sp. and Photobacterium } \\
\text { damselae. } \\
\text { Antibacterial activity of } \\
\text { bacterial strain KU011TH } \\
\text { isolated from bighead catfish } \\
\text { skin mucus against several fish } \\
\text { pathogens. }\end{array}$ & Bunnoy et al. (2019) \\
\hline
\end{tabular}




\begin{tabular}{lll}
\hline Production & of & Flectobacillus major from the Reverter et al. (2018) \\
bioactive & mucous layer of the rainbow \\
components & trout skin produces \\
& sphingolipids which induce \\
& the production of on \\
& immunoglobulin $\mathrm{T}$ (IgT), \\
& forming B lymphocyte cells \\
& and antibody responses, to \\
& control the growth of \\
& pathogenic bacteria.
\end{tabular}

\section{SIGNIFICANCE OF FISH SKIN MUCUS IN WARFARE AGAINST PATHOGENS}

Fishes are a great source of different bioactive substances providing antimicrobial components which are responsible for the antibacterial property of epidermal secretion. Those layers play a key role in defense mechanisms and prevent colonization of harmful pathogens on fish body.

\section{Procedure for determination of antibacterial activity}

Epidermal mucus is dorso-laterally scrapped from fish body with a sterile spatula (Subramanian $\boldsymbol{e t} \boldsymbol{a l}$., 2008) and collected in centrifugation tubes. Then, it is centrifuged at $10000 \mathrm{rpm}$ at $4^{\circ} \mathrm{C}$ for $15 \mathrm{~min}$. Supernatant is collected and preserved until use at $-20^{\circ}$, and pellet is discarded. The centrifuged mucus is used to determine antibacterial activity against pathogenic strains.

The antimicrobial activity of fish epidermal mucus is determined by Agar well diffusion assay according to the standard protocol suggested by Perez et al. (1990).

Wells are cut on pathogenic bacteria seeded solidified nutrient agar plates, and mucus is poured in the wells. After incubation of $24-36 \mathrm{~h}$ at $37^{\circ} \mathrm{C}$, a clear zone of inhibition can be observed around the well. Zone of inhibition is the area on the agar plate where microbial growth does not occur (Fig. 3). The diameter of ZOI reflects the intensity of antibacterial activity of mucus.

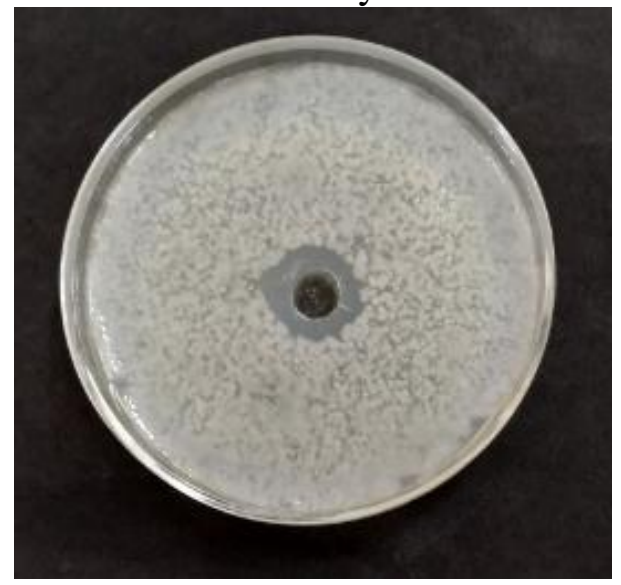

Fig.3. Zone of inhibition around the well with no bacterial growth 
Many studies reporting the antibacterial activity of fish skin mucus against various pathogenic bacteria are described in Table (2).

Table 2. Antibacterial activity of fish skin mucus against bacterial pathogens

\begin{tabular}{|c|c|c|c|c|}
\hline $\begin{array}{l}\text { Sr. } \\
\text { No. }\end{array}$ & Fish species & $\begin{array}{c}\text { Antibacterial } \\
\text { component }\end{array}$ & $\begin{array}{c}\text { Inhibited Bacterial } \\
\text { Strains } \\
\end{array}$ & Reference \\
\hline 1. & $\begin{array}{l}\text { Siganus fuscescens and } \\
\text { S. guttatus }\end{array}$ & $\begin{array}{l}\text { Acidic } \\
\text { Glycoprotein }\end{array}$ & $\begin{array}{l}\text { Several Gram } \\
\text { Negative Bacteria }\end{array}$ & $\begin{array}{l}\text { Nagashima et al. } \\
(2001)\end{array}$ \\
\hline 2. & $\begin{array}{l}\text { Atlantic halibut } \\
\text { (Hippoglossus } \\
\text { hippoglossus L.) }\end{array}$ & $\begin{array}{l}\text { Antimicrobial } \\
\text { Peptide }\end{array}$ & $\begin{array}{lr}\text { Gram Positive and } \\
\text { Gram } \\
\text { Bacteria }\end{array}$ & $\begin{array}{l}\text { Birkemo et al. } \\
(2003)\end{array}$ \\
\hline 3. & $\begin{array}{l}\text { Rockfish } \quad \text { (Sebastes } \\
\text { schlegeli) }\end{array}$ & $\begin{array}{l}\text { Antimicrobial } \\
\text { Protein }\end{array}$ & $\begin{array}{l}\text { A.hydrophila, A. } \\
\text { salmonicida } \\
\text { Photobacterium } \\
\text { damselae ssp. }\end{array}$ & $\underset{(2006)}{\text { Kitani }}$ et $\quad$ al. \\
\hline 4. & $\begin{array}{l}\text { Yellow } \\
\text { (Pelteobagrus } \\
\text { fulvidraco) }\end{array}$ & $\begin{array}{l}\text { Antimicrobial } \\
\text { Peptide }\end{array}$ & $\begin{array}{ll}\text { E. coli, B. subtilis, } S . \\
\text { aureus } \\
\text { albicans }\end{array}$ & Su (2011) \\
\hline 5. & Mastacembelus armatus & Protein & $\begin{array}{l}\text { Human pathogens viz. } \\
\text { E. coli, V. cholera, S. } \\
\text { aureus, Salmonella } \\
\text { typhi, K. pneumonia } \\
\text { and fish pathogens } \\
\text { i.e., Yersinia ruckeri, } \\
\text { A. hydrophila, A. } \\
\text { formican, } \\
\text { liquefaciens, } \\
\text { aeruginosa }\end{array}$ & $\begin{array}{l}\text { Uthayakumar et } \\
\text { al. (2012) }\end{array}$ \\
\hline 6. & $\begin{array}{l}\text { Barbonymus } \\
\text { schwanenfeldii }\end{array}$ & Glycoprotein & $\begin{array}{l}\text { Gram Positive } \\
\text { Bacteria i.e. B. cereus } \\
\text { and S. aureus } \\
\text { Gram Negative } \\
\text { Bacteria i.e. Shigella } \\
\text { boydii and E.coli }\end{array}$ & $\begin{array}{l}\text { Subhashini et al. } \\
\text { (2013) }\end{array}$ \\
\hline
\end{tabular}




\begin{tabular}{|c|c|c|c|c|}
\hline 7. & $\begin{array}{l}\text { Hypophthalmicthys } \\
\text { nobilis }\end{array}$ & Protein & $\begin{array}{l}\text { K. pneumoniae, } P . \\
\text { aeruginosa, E. coli, } S . \\
\text { epidermidis, } S . \text { aureus, } \\
B . \quad \text { cereus and } A . \\
\text { hydrophila }\end{array}$ & $\begin{array}{l}\text { Tyor and Kumari } \\
\text { (2016) }\end{array}$ \\
\hline 8. & Rainbow trout & $\begin{array}{l}\text { Alkaline } \\
\text { Phosphatase }\end{array}$ & $\begin{array}{l}\text { A. hydrophila and } \\
\text { Yersinia ruckerii }\end{array}$ & Taee et al. (2017) \\
\hline 9. & $\begin{array}{l}\text { Hypophthalmichthys } \\
\text { nobilis, } \\
\text { Ctenopharyngodon } \\
\text { idella and Cyprinus } \\
\text { carpio }\end{array}$ & Protein & $\begin{array}{l}\text { K. pneumoniae, } P . \\
\text { aeruginosa, E. coli, } S . \\
\text { epidermidis, S. aureus, } \\
B . \quad \text { cereus and } A . \\
\text { hydrophila }\end{array}$ & $\underset{(2019)}{\text { Kumari }}$ et al. \\
\hline 10. & Anabas Testudines & $\begin{array}{l}\text { Lysozyme and } \\
\text { Proteases }\end{array}$ & $\begin{array}{lr}S . \quad \text { aureus, } & P . \\
\text { aeruginosa, } & S . \\
\text { choleraesuis, } & B . \\
\text { subtilis and Serratia } \\
\text { marcencen } \mathrm{S} 381\end{array}$ & $\begin{array}{l}\text { Al-rasheed et al. } \\
(2020)\end{array}$ \\
\hline
\end{tabular}

\section{METHODS OF ISOLATING BACTERIA FROM FISH SKIN MUCUS}

i. This experiment is performed according to standard protocol by Bunnoy et al. (2019). The epidermal mucus is dorso-laterally scrapped from fish body and serial dilution is done in physiological saline $(0.85 \% \mathrm{NaCl})$. Then, $100 \mu 1$ is poured and spread on solidified nutrient agar plate (containing $0.5 \%$ tryptone, $0.3 \%$ yeast extract, $1 \%$ glucose and $1.5 \%$ agar), and an incubation was done at $32^{\circ} \mathrm{C}$ for $24 \mathrm{~h}$. After incubation, any morphologically distinct bacterial colony is picked up and subcultured in nutrient broth media (containing $0.5 \%$ tryptone, $0.3 \%$ yeast extract and $1 \%$ glucose) for $24 \mathrm{~h}$. Bacterial culture is subjected to centrifugation at 3000rpm for 5 min for segregation, and suspension is made in glycerol $(20 \% \mathrm{v} / \mathrm{v})$ to store at $-80^{\circ} \mathrm{C}$ for further use. Microscopic examination of bacterial colony and cell morphology must be performed to ensure the pure culture of bacteria and also to eliminate any kind of contamination.

ii. The isolation of bacterial strain from fish skin mucus is performed by the standard procedure given by Boutin et al. (2012). Sterile cotton swab is used to gently dab the fish skin to collect mucus, and then it is placed into $500 \mu \mathrm{l}$ of filter-sterilized $(0.22$ $\mu \mathrm{m})$ artificial seawater for about $20 \mathrm{~min}$. After amalgamating the swab in the ASW in a fast motion, the swab is taken out, and $100 \mu \mathrm{l}$ of the artificial seawater solution is poured and spread on a marine agar plate. A 1:100 dilution of the inoculated artificial seawater solution is made, and $100 \mu \mathrm{l}$ is poured on different marine agar plate. Plates secured with parafilm are placed at room temperature and morphologically distinct bacterial individual colonies are repeatedly streaked for isolation of pure culture on fresh marine agar plates and incubated for $24-48 \mathrm{~h}$ at room temperature. Then, the 
pure isolated bacterial strains are streaked on marine agar slants and stored for further usage.

iii. Bacteria are isolated from fish epidermal mucus following the steps described in the study of Subramanian et al. (2008). Mucus is collected by gently moving the fish into a polythene bag containing $10 \mathrm{ml}$ salt solution $(100 \mathrm{mM} \mathrm{NaCl})$. The fish is carefully moved backwards and forwards for approx. 1-2 min to release the epidermal secretion. The resultant mucus salt solution is poured in sterilized eppendorf tubes, centrifuged at $10000 \mathrm{rpm}$ for $15 \mathrm{~min}$ and preserved at $-20^{\circ} \mathrm{C}$ until use. The isolation of bacterial strains is done by spreading the mucus on nutrient agar plate followed by incubation at $37^{\circ} \mathrm{C}$ for $24 \mathrm{~h}$. Individual colonies are then picked up based on difference in shape, size and colour and repeatedly streaked on separate agar plates for 24-36 $\mathrm{h}$ to obtain the pure culture. Isolated strains are then cultured in nutrient broth medium and stored at $4^{\circ} \mathrm{C}$ until use.

\section{METHOD OF IDENTIFYING ISOLATED BACTERIA BY USING 16S rDNA BASED MOLECULAR TECHNIQUE}

The bacterial strains, isolated from fish epidermal mucus which produce clear zone of inhibition against pathogenic bacteria, are identified by using 16S rDNA based molecular technique in which nucleotide homology and Phylogenetic tree analysis is done to identify the isolated bacterial strain. Steps involved in this technique are mentioned below-

i. Isolated bacterial strain is processed to isolate DNA, and $1.2 \%$ agarose gel is used to estimate quality.

ii. After that, 99 well Thermal Cycler is used to amplify the isolated DNA with 16S rRNA Specific Primer (8F and 1492R).

iii. The PCR amplicon thus obtained is enzymatically purified and Sanger Sequencing is done.

iv. DNA sequencing reaction of PCR amplicon is carried out bi- directionally with 704F and 907R primers using BDT v3.1 Cycle sequencing kit on ABI 3730xl Genetic Analyzer.

v. Aligner software is used to generate consensus sequence of $16 \mathrm{~S}$ rDNA from forward and reverse sequence data.

vi. The $16 \mathrm{~S}$ rDNA sequence is utilized to perform BLAST alignment search tool of NCBI Genbank database.

vii. Initial fifteen sequences are selected based on maximum identity score and aligned using multiple alignment software programs.

viii. RDP database is employed to generate distance matrix and MEGAX is used to construct Phylogenetic tree.

\section{FISH MUCUS AS SOURCE OF NEXT GENERATION ANTIBIOTICS}

Antibiotic resistance is one of the major public health issues. It arises when infectious pathogens such as bacteria, fungi and virus develop their capability to beat the medicines or drugs which are administered to eliminate them and can affect people at any stage of life. This crisis has been ascribed to the misuse/overuse and lack of replacement of these types of drugs. 
Due to widespread antibiotic resistance and increasing bacterial infections, next generation antibiotics are strongly needed.

Fishes are prone to several bacterial, fungal and viral infections in the aquatic ecosystem, but they guard themselves from these pathogenic infections with the help of various complex defense mechanism systems, and their skin mucus provides the first line of defence. Fish epidermal mucus performs several functions including respiration, reproduction, sibling recognition, disease resistance etc. Goblet cells in fish epidermis secrete a layer of slimy secretion on their surface that is a viscous colloid composed of mucins, antibacterial peptides, proteins, glycoproteins and antipathogenic bacteria. All these are the essential components in attaining the innate immunity in fishes. These antibacterial components can be utilized as a source of novel and next generation drugs as they show antibacterial/antipathogenic effect against pathogenic Bacterial strains. Replacement of antibiotics with these novel antibiotic components obtained from fish epidermal mucus by non - invasive method (without harming or killing the fish) is not only advantageous against antibiotic resistance of multidrug resistant pathogens affecting fishes but would also help in the treatment of deadly diseases in human.

\section{FISH SKIN MUCUS IN COMPARISON TO COMMONLY USED ANTIBIOTICS}

Fish epidermal mucus is a protective barrier preventing the colonization of infectious pathogens upon fish skin surface. It consists of several antibacterial components, which are responsible for the antibacterial activity of fish epidermal mucus against several human and fish pathogens. Thus, it can be used as an alternate to antibiotics to cope with the serious problem of antibiotic resistance. Many studies have been conducted to compare the antibacterial effect of fish epidermal mucus with commonly used antibiotics against various human and fish pathogens. Antibacterial activity is measured in the form of zone of inhibition (ZOI) in $\mathrm{mm}$, which is the numerical value of potential of any antibacterial agent to inhibit the growth of a pathogen. Antibacterial effect is attributed to the pore forming properties of antibacterial components entangled in fish epidermal mucus which cause the lysis of bacterial strains.

Kuppulakshmi et al. (2008) observed strong antibacterial activity of fish epidermal mucus of $C$. punctatus and $C$. mrigala against $S$. aureus, V. cholera and L. vulgaris, which was higher than the antibacterial effect exhibited by antibiotic Chloramphenicol.

Fish epidermal mucus of $C$. catla showed ZOI of $32 \mathrm{~mm}$ against pathogen $S$. typhi, which was higher than the value of antibiotic Ciprofloxacin $(28 \mathrm{~mm})$ as depicted by Balasubramanian et al. (2012). Tyor and Kumari (2016) studied the antibacterial effect of fish epidermal mucus of $H$. nobilis against different bacterial strains and compared the results with the value of ZOI obtained by using antibiotic Chloramphenicol as antibacterial agent. Results reported better antibacterial effect of fish epidermal mucus than antibiotic Chloramphenicol.

Furthermore, Kumari et al. (2019) reported stronger antibacterial effect of crude healthy fish epidermal mucus of $H$. nobilis, $C$. idella and $C$. carpio as compared to the antibiotic Chloramphenicol against various pathogens such as $P$. aeruginosa, E. coli, S. epidermidis, $S$. aureus, B. cereus and A. hydrophila.

The fish skin mucus is a reservoir of antibacterial components which are responsible for its antibacterial effect against several human and fish pathogens and provides better results when used in comparison to commonly used antibiotics. Thus, fish epidermal mucus can be utilized to 
replace the antibiotics for treatment of bacterial diseases in fishes as well as human. The use of antibacterial components of fish epidermal mucus can be useful in solving the issue of antibiotic resistance, which is rising as a worldwide problem and threatening the advancement in healthcare and life expectancy.

\section{CONCLUSION AND FUTURE ASPECTS}

The study addressed and analyzed the above- mentioned preceding studies and the importance of fish skin mucus in various biological, ecological and physiological roles in the innate immunity and the well- being of fish. It was concluded that, the fish cutaneous mucus has the potential to be an easy, non- invasive and reliable method to be utilized as a vital tool for the aquaculture. Its efficacy was proved in disease resistance, disease treatment and successful intensification as well as sustainability of aquaculture. Further research is recommended with respect to the mechanism through which probiotic bacteria is isolated from fish skin mucus exerting their effect on host.

Since little attention has been paid to the antimicrobial properties of marine fish skin mucus, future research is required to focus on investigating and exploring the properties of marine fish skin mucus and utilize this as an effective resource of novel antimicrobial clinically relevant compounds. In addition, future research is needed to explore the potential of living and nonliving antimicrobial components of fish skin mucus to be utilized as novel drug/medicine. Furthermore, innovative and advanced technologies are needed to commercialize the antimicrobial components on industrial basis for the sustainable aquaculture as well as for the treatment of lethal human diseases such as bacterial diseases and cancer etc.

\section{REFERENCES}

Abbas, F.; Hafeez-ur-Rehman; M., Ashraf; M., Iqbal, K.; Andleeb, S. and Khan, B. (2020). Mucus properties of Chinese carp and Indian carp: Physical barrier to pathogens. Iran. J. Fish. Sci., 193(3): 1224-1236.

Abdullah, N.S. and Saad, S. (2015). Rapid detection of N-acetylneuraminic acid from false clownfish using HPLC-FLD for symbiosis to host sea anemone. Asian J. Appl. Sci., 3(5).

Al-Rasheed, A.; Handool, K.O.; Alhelli, A. M.; Garba, B.; Muhialdin, B.J.; Masomian, M.; Hani, H. and Daud, H.H.M. (2020). Assessment of Some Immune Components from The Bioactive Crude Extract Derived from The Epidermal Mucus of Climbing Perch Anabas Testudines. Turkish J. Fish. Aquat. Sci, 20(10): 755 -766.

Al-Zaidan, A.S.; Endo, M.; Maita, M.; Gonçalves, A.T.; Futami, K. and Katagiri, T. (2013). A toxicity bioassay study concerning the effect of un-ionized ammonia on the mucus cells response originating from the gills of zebrafish Danio rerio. Fish Sci., 79(1): 129-142.

Aranishi, F. and Nakane, M. (1997). Epidermal proteases of the Japanese eel. Fish Physiol. Biochem., 16:471-478.

Aranishi, F.; Mano, N. and Hirose, H. (1998). Fluorescence localization of epidermal cathepsins L and B in the Japanese eel. Fish Physiol. Biochem., 19, 205-209.

Arasu, A.; Kumaresan, V.; Sathyamoorthi, A.; Palanisamy, R.; Prabha, N.; Bhatt, P.; Roy, A.; Thirumalai, M.K.; Gnanam, A. J.; Pasupuleti, M. and Marimuthu, K. (2013). Fish lily type lectin- 1 contains $\beta$-prism architecture: Immunological characterization. Mol. Immunol., 56(4), 497-506. 
Arockiaraj, J.; Gnanam, A. J.; Muthukrishnan, D.; Gudimella, R.; Milton, J.; Singh, A.; Muthupandian, S.; Kasi, M. and Bhassu, S. (2013). Crustin, a WAP domain containing antimicrobial peptide from freshwater prawn Macrobrachium rosenbergii: immune characterization. Fish Shellfish Immunol., 34(1): 109-118.

Bader, J.A.; Nusbaum, K.E. and Shoemaker, C.A. (2003). Comparative challenge model of Flavobacterium columnare using abraded and unabraded channel catfish, Ictalurus punctatus (Rafinesque). J. Fish Dis., 26(8): 461-467.

Baker, C.F. and Hicks, B.J. (2003). Attraction of migratory inanga (Galaxias maculatus) and koaro (Galaxias brevipinnis) juveniles to adult galaxiid odours. N. Z. J. Mar. Freshwater Res., 37(2):291-299.

Balasubramanian, S.; Prakash, M.; Senthilraja, P. and Gunasekaran, G. (2012). Antimicrobial properties of skin mucus from four freshwater cultivable fishes (Catla catla, Hypophthalmichthys molitrix, Labeo rohita and Ctenopharyngodon idella). Afr. J. Microbiol. Res., 6(24): 5110-5120.

Bernadsky, G. and Rosenberg, E. (1992). Drag-reducing properties of bacteria from the skin mucus of the cornetfish (Fistularia commersonii). Microb. Ecol., 24(1): 63-76.

Birkemo, G.A.; Lüders, T.; Andersen, Ø.; Nes, I.F. and Nissen-Meyer, J. (2003). Hipposin, a histone-derived antimicrobial peptide in Atlantic halibut (Hippoglossus hippoglossus L.). Biochim Biophys Acta Proteins Proteom BBAPROTEINS PROTEOM, 1646(1-2): 207-215.

Boshra, H.; Li, J. and Sunyer, J.O. (2006). Recent advances on the complement system of teleost fish. Fish shellfish Immunol., 20(2): 239-262.

Boutin, S.; Bernatchez, L.; Audet, C. and Derôme, N. (2012). Antagonistic effect of indigenous skin bacteria of brook charr (Salvelinus fontinalis) against Flavobacterium columnare and F. psychrophilum. Vet. Microbiol., 155(2-4): 355-361.

Bunnoy, A.; Na-Nakorn, U.; Kayansamruaj, P. and Srisapoome, P. (2019). Acinetobacter strain KUO11TH, a unique organism related to Acinetobacter pittii and isolated from the skin mucus of healthy bighead catfish and its efficacy against several fish pathogens. Microorganisms. 7(11): 549.

Cha, G.H.; Liu, Y.; Peng, T.; Huang, M.Z.; Xie, C.Y.; Xiao, Y.C. and Wang, W.N. (2015). Molecular cloning, expression of a galectin gene in Pacific white shrimp Litopenaeus vannamei and the antibacterial activity of its recombinant protein. Mol. Immunol., 67(2): 325-340.

Chabrillón, M.; Rico, R.M.; Balebona, M.C. and Moriñigo, M.C. (2005) Adhesions to sole, Solea senegalensis Kaup, mucus of microorganisms isolated from farmed fish, and their interaction with Photobacterium damselae subsp. piscicida. J Fish Dis., 28: 229-237.

Clark, E. (1974). The Red Sea's sharkproof fish. Nat. Geo., 146(5): 719-727.

Cone, R. A. (2009). Barrier properties of mucus. Adv. Drug Deliv. Rev., 61(2): 75-85.

Cordero, H.; Brinchmann, M.F.; Cuesta, A.; Meseguer, J. and Esteban, M.A. (2015). Skin mucus proteome map of European sea bass (Dicentrarchus labrax). Proteomics. 15(2324): 4007-4020.

Costa-Neto, E.M. (2005). Animal-based medicines: biological prospection and the sustainable use of zootherapeutic resources. Anais da Academia Brasileira de ciências, 77(1): 33-43.

Dash, S.; Das, S.K.; Samal, J.; Ojha, P.K.; Patra, J.K. and Thatoi, H. (2011). Dose dependence specific and non-specific immune responses of Indian major carp (L. rohita 
Ham.) to intraperitoneal injection of formalin killed Aeromonas hydrophila whole cell vaccine. Vet. Res. Commun., 35(8): 541-552.

Dash, S.; Samal, J. and Thatoi, H. (2014). A comparative study on innate immunity parameters in the epidermal mucus of Indian major carps. Aquac. Int. 22(2): 411-421.

Denis, M.; Palatty, P.M.; Bai, N.R. and Suriya, S.J. (2003). Purification and characterization of a sialic acid specific lectin from the hemolymph of the freshwater crab Paratelphusa jacquemontii. Eur. J. Biochem., 270(21): 4348-4355.

Dobretsov, S.V. and Qian, P.Y. (2002). Effect of bacteria associated with the green alga Ulva reticulata on marine micro and macrofouling. Biofouling, 18(3): 217-228.

Easy, R.H. and Ross, N.W. (2009). Changes in Atlantic salmon (Salmo salar) epidermal mucus protein composition profiles following infection with sea lice (Lepeophtheirus salmonis). Comp. Biochem. Physiol. Part. D. 4:159-167.

Easy, R.H. and Ross, N.W. (2010). Changes in Atlantic salmon Salmo salar mucus components following short and long term handling stress. J. Fish Biol., 77(7): 1616-1631.

Fan, C.; Wang, J.; Zhang, X. and Song, J. (2015). Functional C1q is present in the skin mucus of Siberian sturgeon (Acipenser baerii). Integr. Zool., 10(1): 102-110.

Fast, M.D.; Sims, D.E.; Burka, J.F.; Mustafa, A. and Ross, N.W. (2002). Skin morphology and humoral non-specific defence parameters of mucus and plasma in rainbow trout, coho and Atlantic salmon. Comp. Biochem. Physiol. Part A: Molecular \& Integrative Physiology, 132(3): 645-657.

Fekih-Zaghbib, S.; Fildier, A.; Barrek, S. and Bouhaouala-Zahar, B. (2013). A complementary LC-ESI-MS and MALDI-TOF approach for screening antibacterial proteomic signature of farmed European Sea bass mucus. Fish Shellfish Immunol., 35(2): 207-212.

Fernandes, J.M.; Molle, G.; Kemp, G.D. and Smith, V.J. (2004). Isolation and characterisation of oncorhyncin II, a histone H1-derived antimicrobial peptide from skin secretions of rainbow trout, Oncorhynchus mykiss. DEV COMP IMMUNOL., 28(2): 127138.

Fernández-Alacid, L.; Sanahuja, I.; Ordóñez-Grande, B.; Sánchez-Nuño, S.; Viscor, G.; Gisbert, E.; Herrera, M. and Ibarz, A. (2018). Skin mucus metabolites in response to physiological challenges: a valuable non-invasive method to study teleost marine species. Sci. Total Environ., 644: 1323-1335.

Fuente, M.D.L.; Miranda, C.D.; Jopia, P.; González-Rocha, G.; Guiliani, N.; Sossa, K. and Urrutia, H. (2015). Growth inhibition of bacterial fish pathogens and quorum-sensing blocking by bacteria recovered from Chilean salmonid farms. J. Aquat. Anim. Health, 27(2): 112-122.

Fuller, R. (1989). Probiotics in man and animals. J. Appl. Bacteriol., 66: 365-378.

Fuochi, V.; Volti, G.L.; Camiolo, G.; Tiralongo, F.; Giallongo, C.; Distefano, A.; Petronio-Petronio, G.; Barbagallo, I.; Viola, M. and Furneri, P. M. (2017). Antimicrobial and anti-proliferative effects of skin mucus derived from Dasyatis pastinaca (Laennaeus 1758). Mar. Drugs., 15: 372.

Gewurz, H.; Zhang, X.H. and Lint, T.F. (1995). Structure and function of the pentraxins. Curr. Opin. Immunol., 7(1): 54-64.

Ghalambor, M.; Eslamifar, Z. and Khoshnood, Z. (2020). Biochemical characterization of lysozyme extracted from Common Carp, Cyprinus carpio. Ecopersia., 8(2): 125 -131. 
Gómez, D.; Sunyer, J.O. and Salinas, I. (2013). The mucosal immune system of fish: The evolution of tolerating commensals while fighting pathogens. Fish. Shellfish Immunol., 35: 1729-1739.

Guardiola, F.A.; Cuesta, A.; Arizcun, M.; Meseguer, J. and Esteban, M. A. (2014). Comparative skin mucus and serum humoral defence mechanisms in the teleost gilthead seabream (Sparus aurata). Fish. Shellfish Immunol., 36(2): 545-551.

Hamada, M.; Nagai, T.; Kai, N.; Tanoue, Y.; Mae, H.; Hashimoto, M.; Miyoshi, K. Kumagai, H. and Saeki, K. (1995). Inorganic constituents of bone of fish. Fish. Sci., 61(3): 517-520.

Hancock, R.E. and Scott, M.G. (2000). The role of antimicrobial peptides in animal defenses. PNAS., 97(16): 8856-8861.

Harder T.; Lau S.C.K.; Dobretsov, S.; Fang, T.K. and Qian, P.Y. (2003). A distinctive epibiotic bacterial community on the soft coral Dendronephthya sp. and antibacterial activity of coral tissue extracts suggest a chemical modification against bacterial epibiosis. FEMS Microbiol. Ecol., 43: 337-347.

Hartley, B. S. (1960). Proteolytic enzymes. Annu. Rev. Biochem., 29(1): 45-72.

Hepper, P.G. (1991). An examination of fetal learning before and after birth. Ir. J. Psychol., 12(2): 95-107.

Huertas, M.; Hubbard, P.C.; Canario, A.V.M. and Cerda, J. (2007). Olfactory sensitivity to conspecific bile fluid and skin mucus in the European eel Anguilla anguilla (L.). J. Fish. Biol., 70: 1907-1920.

Huertas, M.; Scott, A.P.; Hubbard, P.C.; Canario, A.M. and Cerda, J. (2006). Sexually mature European eels (Anguilla anguilla L.) stimulate gonadal development of neighbouring males: possible involvement of chemical communication. Gen. Comp. Endocrinol., 147: 304313.

Iger, Y. and Abraham, M. (1990). The process of skin healing in experimentally wounded carp. J. Fish Biol., 36(3): 421-437.

Iger, Y. and Abraham, M. (1997). Rodlet cells in the epidermis of fish exposed to stressors. Tissue and Cell, 29(4): 431-438.

Iger, Y.; Abraham, M. and Bonga, S.W. (1994). Response of club cells in the skin of the carp Cyprinus carpio to exogenous stressors. Cell Tissue Res., 277(3): 485-491.

Ingram, G.A. (1980). Substances involved in the natural resistance of fish to infection-a review. J. Fish. Biol., 16(1): 23-60.

Itoi, S.; Yoshikawa, S.; Asahina, K.; Suzuki, M.; Ishizuka, K. and Sugita, H. (2014). Larval pufferfish protected by maternal tetrodotoxin. Toxicon., 78: 35-40.

Kallert, D.M.; Bauer, W.; Haas, W. and El-Matbouli, M. (2011). No shot in the dark: Myxozoans chemically detect fresh fish. Int. J. Parasitol., 41: 271-276.

Kennedy, J.; Baker, P.; Piper, C.; Cotter, P.D.; Walsh, M.; Mooij, M. J.; Bourke, M.B.; Rea, M.C.; O'Connor, P.M.; Ross, R.P. and Hill, C. (2009). Isolation and analysis of bacteria with antimicrobial activities from the marine sponge Haliclona simulans collected from Irish waters. Mar. Biotechnol., 11(3): 384-396.

Kiernan J. A. (2008). Histological and Histochemical methods: theory and practice, 4th edn. Cold Spring Harbor Laboratory, Boston, MA.

Klesius, P.H.; Shoemaker, C.A. and Evans, J. J. (2008). Flavobacterium columnare chemotaxis to channel catfish mucus. FEMS Microbiol. Lett., 288: 216-220. 
Kumari, S. (2018). Identification and comparison of antibacterial components in the fish mucus of freshwater fishes of different feeding habits and habitats (Thesis). Kurukshetra University Kurukshetra, Haryana, India.

Kumari, S.; Tyor, A.K. and Bhatnagar, A. (2019). Evaluation of the antibacterial activity of skin mucus of three carp species. Int. Aquat. Res., 11(3): 225-239.

Kuppulakshmi, C.; Prakash, M.; Gunasekaran, G.; Manimegalai, G. and Sarojini, S. (2008). Antibacterial properties of fish mucus from Channa punctatus and Cirrhinus mrigala. Eur. Rev. Medi Pharmacol Sci., 12: 149-153.

Lallès, J.P. (2019). Biology, environmental and nutritional modulation of skin mucus alkaline phosphatase in fish: A review. Fish shellfish Immunol., 89:179-186.

Landeira-Dabarca, A.; Álvarez, M. and Molist, P. (2014). Food deprivation causes rapid changes in the abundance and glucidic composition of the cutaneous mucous cells of Atlantic salmon Salmo salar L. J. Fish Dis., 37(10): 899-909.

Larsen, M.H.; Larsen, J.L. and Olsen, J.E. (2001). Chemotaxis of Vibrio anguillarum to fish mucus: Role of the origin of the fish mucus, the fish species and the serogroup of the pathogen. FEMS Microbiol. Ecol., 38: 77-80.

Lee, S.A.; Kim, Y.K.; Lim, S.S.; Zhu, W.L.; Ko, H.; Shin, S.Y.; Hahm, K.S. and Kim, Y. (2007). Solution structure and cell selectivity of piscidin 1 and its analogues. Biochemistry. 46(12):3653-3663.

Lee-Huang, S.; Huang, P.L.; Sun, Y.; Huang, P.L.; Kung, H.F.; Blithe, D.L. and Chen, H. C. (1999). Lysozyme and RNases as anti-HIV components in $\beta$-core preparations of human chorionic gonadotropin. PNAS. 96(6): 2678-2681.

León-Sicairos, N.; López-Soto, F.; Reyes-López, M.; Godínez-Vargas, D.; OrdazPichardo, C. and De La Garza, M. (2006). Amoebicidal activity of milk, apo-lactoferrin, sIgA and lysozyme. Clin. Med. Res., 4(2): 106-113.

Lesser, M.P.; Farrell, J.H. and Walker, C.W. (2001). Oxidative stress, DNA damage and p53 expression in the larvae of Atlantic cod (Gadus morhua) exposed to ultraviolet (290-400 nm) radiation. J. Exp. Biol., 204(1): 157-164.

Leyton, Y. and Riquelme, C. (2010). Marine Bacillus spp. associated with egg capsules of Concholepas concholepas (common name 'Loco') have an inhibitory activity toward the pathogen Vibrio parahaemolyticus. Microb. Ecol., 60: 599-605.

Liu, L.; Li, C.; Su, B.; Beck, B.H. and Peatman, E. (2013). Short-term feed deprivation alters immune status of surface mucosa in Channel Catfish (Ictalurus punctatus). PLoS ONE, 8(9): 1-10.

Lowrey, L.; Woodhams, D.C.; Tacchi, L. and Salinas, I. (2015). Topographical mapping of the rainbow trout (Oncorhynchus mykiss) microbiome reveals a diverse bacterial community with antifungal properties in the skin. Appl. Environ. Microbiol., 81(19): 69156925.

Lowry, O.H.; Rosenbrough, N.J.; Farr, A.L. and Randall, R.J. (1951). Protein measurement with the folin phenol reagent. J. Biol. Chem., 193: 265-275.

Magnadottir, B.; Lange, S.; Gudmundsdottir, S.; Bøgwald, J. and Dalmo, R.A. (2005). Ontogeny of humoral immune parameters in fish. Fish Shellfish Immunol., 19(5): 429-439.

Mathuru, A.S.; Kibat, C.; Cheong, W.F.; Shui, G.; Wenk, M.R.; Friedrich, R.W. and Jesuthasan, S. (2012). Chondroitin fragments are odorants that trigger fear behavior in fish. Curr. Biol., 22(6): 538-544.

Matsumura, K. (1995). Tetrodotoxin as a pheromone. Nature. 378: 563-564. 
Matsumura, K.; Matsunaga, S. and Fusetani, N. (2004). Possible involvement of phosphatidylcholine in school recognition in the catfish, Plosotus lineatus. Zool. Sci., 21: 256-264.

Matsushita, M.; Matsushita, A.; Endo, Y.; Nakata, M.; Kojima, N.; Mizuochi, T. and Fujita, T. (2004). Origin of the classical complement pathway: Lamprey orthologue of mammalian C1q acts as a lectin. PNAS. 101(27): 10127-10131.

Merrifield, D.L.; Dimitroglou, A.; Foey, A.; Davies, S.J.; Baker, R.T.; Bøgwald, J.; Castex, M. and Ringø, E. (2010). The current status and future focus of probiotic and prebiotic applications for salmonids. Aquaculture. 302(1-2): 1-18.

Message, G.M. (1984). Practical aspects of gas chromatography / mass spectrometry. Wiley, New York.

Mozumder, M.M.H. (2005). Antibacterial activity in fish mucus from farmed fish (Master's thesis, Universitetet i Troms $\emptyset$ ).

Nagashima, Y.; Sendo, A.; Shimakura, K.; Shiomi, K.; Kobayashi, T.; Kimura, B. and Fujii, T. (2001). Antibacterial factors in skin mucus of rabbitfishes. J. Fish Biol., 58(6):17611765.

Nauta, A.J.; Daha, M.R.; van Kooten, C. and Roos, A. (2003). Recognition and clearance of apoptotic cells: a role for complement and pentraxins. Trends Immunol., 24(3): 148-154.

Nigam, A.K.; Kumari, U.; Mittal, S. and Mittal, A.K. (2012). Comparative analysis of innate immune parameters of the skin mucous secretions from certain freshwater teleosts, inhabiting different ecological niches. Fish Physiol. Biochem. 38(5): 1245-1256.

Nonaka, M. and Miyazawa, S. (2001). Evolution of the initiating enzymes of the complement system. Genome biol., 3(1): 1001-1.

Novák, M. (1965). Colorimetric ultramicro method for the determination of free fatty acids. J. Lipid Res., 6(3): 431-433.

O'Brien, J. and Wright, G.D. (2011). An ecological perspective of microbial secondary metabolism. Curr. Opinion Biotechnol., 22: 552-558.

Ohashi, H.; Umeda, N.; Hirazawa, N.; Ozaki, Y.; Miura, C. and Miura, T. (2007). Purification and identification of a glycoprotein that induces the attachment of oncomiracidia of Neobenedenia girellae (Monogenea, Capsalidae). Int. J. Parasitol., 37: 1483-1490.

Ottinger, C.A.; Johnson, S.C.; Ewart, K.V.; Brown, L.L. and Ross, N.W. (1999). Enhancement of anti- Aeromonas salmonicida activity in Atlantic salmon (Salmo salar) macrophages by a mannose-binding lectin. Comp. Biochem. Physiol. Part C: Pharmacology, Toxicology and Endocrinology, 123(1): 53-59.

Penesyan, A.; Kjelleberg, S. and Egan, S. (2010). Development of novel drugs from marine surface associated microorganism. Mar. Drugs., 8: 438-459.

Perez, C.; Pauli, M. and Bazerque, P. (1990). An Antibiotic Assay by Agar Well Diffusion Method. Acta Biologiae et Medicinae Experimentalis., 15: 113-115.

Pfeiffer, W. (1977). The distribution of fright reaction and alarm substance cells in fishes. Copeia. 653-665.

Pfennig, D.W. and Sherman, P.W. (1995). Kin recognition. Sci. Am., 272(6): 98-103.

Qasba, P.K. and Kumar, S. (1997). Molecular divergence of lysozymes and alactalbumin. Crit. Rev. Biochem. Mol. Biol., 32: 255-306.

Rai, A.K. and Mittal, A.K. (1983). Histochemical response of alkaline phosphatase activity during the healing of cutaneous wounds in a cat-fish. Experientia, 39(5): 520-522. 
Raj, V.S.; Fournier, G.; Rakus, K.; Ronsmans, M.; Ouyang, P.; Michel, B.; Delforges, C.; Costes, B.; Farnir, F.; Leroy, B. and Wattiez, R. (2011). Skin mucus of Cyprinus carpio inhibits cyprinid herpesvirus 3 binding to epidermal cells. Vet. Res., 42(1): 92.

Rajan, B.; Fernandes, J.M.; Caipang, C.M.; Kiron, V.; Rombout, J.H. and Brinchmann, M. F. (2011). Proteome reference map of the skin mucus of Atlantic cod (Gadus morhua) revealing immune competent molecules. Fish Shellfish Immunol., 31(2): 224-231.

Rajan, B.; Lokesh, J.; Kiron, V. and Brinchmann, M.F. (2013). Differentially expressed proteins in the skin mucus of Atlantic cod (Gadus morhua) upon natural infection with Vibrio anguillarum. BMC Vet. Res., 9(1): 103.

Rakers, S.; Lars, N.; Dieter, S.; Charli, K.; Jurgen, S.; Kristina, S. and Ralf, P. (2013). Antimicrobial peptides (AMPs) from fish epidermis: perspectives for investigative dermatology. J. Invest. Dermatol., 133: 1140-1149.

Ramos, F. and Smith, A.C. (1978). The C-reactive protein (CRP) test for the detection of early disease in fishes. Aquaculture. 14(3): 261-266.

Reverter, M.; Tapissier-Bontemps, N.; Lecchini, D.; Banaigs, B. and Sasal, P. (2018). Biological and ecological roles of external fish mucus: a review. Fishes. 3(4): 41.

Salinas, I. (2015). The mucosal immune system of teleost fish. Biology., 4: 525-539.

Salinas, I.; Zhang, Y.A. and Sunyer, J.O. (2011). Mucosal immunoglobulins and B cells of teleost fish. Dev. Comp. Immuol., 35(12): 1346-1365.

Sar, N. and Rosenberg, E. (1989). Fish skin bacteria: Production of friction-reducing polymers. Microb. Ecol., 17: 27-38.

Shai, Y. (2002). From innate immunity to de-novo designed antimicrobial peptides. Curr. Pharm. Des., 8(9): 715-725.

Shephard, K.L. (1993). Mucus on the epidermis of fish and its influence on drug delivery. Adv. Drug Deliv. Rev., 11(3): 403-417.

Smith, P.K. (1985). Measurement of protein using bicinchonic acid. Anal. Biochem., 150: 76-85.

Smith, R.J.F. (1992). Alarm signals in fishes. Rev. Fish. Biol. Fish., 2: 33-63.

Spanggaard, B.; Huber, I.; Nielson, J. and Sick, E.B. (2001). The probiotic potential against vibriosis of the indigenous microflora of rainbow trout. Environ. Microbiol., 3: 755765

Stabell, O.B. and Selset, R. (1980). Comparison of mucus collecting methods in fish olfaction. Acta Physiologica Scandinavica., 108: 91-96.

Stacey, N. and Sorensen, P. (2002). Hormonal pheromones in fish. In Hormones, brain and behavior (pp. 375-434). Academic Press.

Stevens, J.L.; Jackson, R.L. and Olson, J.B. (2016). Bacteria associated with lionfish (Pterois volitans/miles complex) exhibit antibacterial activity against known fish pathogens. Mar. Ecol. Prog. Ser., 558: 167-180.

Stowell, S.R.; Arthur, C.M.; McBride, R.; Berger, O.; Razi, N.; Heimburg-Molinaro, J.; Rodrigues, L.C.; Gourdine, J.P.; Noll, A.J.; Von Gunten, S. and Smith, D.F. (2014). Microbial glycan microarrays define key features of host-microbial interactions. Nat. Chem. Biol., 10(6): 470-476.

Su, Y. (2011). Isolation and identification of pelteobagrin, a novel antimicrobial peptide from the skin mucus of yellow catfish (Pelteobagrus fulvidraco). Comp. Biochem. Physiol. Part B: Biochem. Mol. Biol., 158(2):149-154. 
Subhashini, S.; Lavanya, J.; Jain, S. and Agihotri, T. (2013). Screening of antibacterial and cytotoxic activity of extracts from epidermis and epidermal mucus of Barbonymus schwanenfeldii (Tinfoil barb fish). Int. J. Eng. Res. Technol., 2(04): 492-497.

Subramanian, S.; MacKinnon, S.L. and Ross, N.W. (2007). A comparative study on innate immune parameters in the epidermal mucus of various fish species. Comp. Biochem. Physiol. Part B: Biochem. Mol. Biol., 148(3): 256-263.

Subramanian, S.; Ross, N.W. and MacKinnon, S.L. (2008). Comparison of antimicrobial activity in the epidermal mucus extracts of fish. Comp. Biochem. Physiol. B., 150: 85-92.

Sung, W.S.; Lee, J. and Lee, D.G. (2008). Fungicidal effect and the mode of action of piscidin 2 derived from hybrid striped bass. Biochem. Biophys. Res., 371(3): 551-555.

Tachibana, K.; Sakaitanai, M. and Nakanishi, K. (1984). Pavoninins: shark-repelling ichthyotoxins from the defense secretion of the Pacific sole. Science. 226(4675): 703-705.

Taee, H.M.; Hajimoradloo, A.; Hoseinifar, S.H. and Ahmadvand, H. (2017). Dietary Myrtle (Myrtus communis L.) improved non-specific immune parameters and bactericidal activity of skin mucus in rainbow trout (Oncorhynchus mykiss) fingerlings. Fish Shellfish Immunol., 64: 320-324.

Takeuchi, M.; Fujiwara-Nagata, E.; Katayama, T. and Suetake, H. (2021). Skin bacteria of rainbow trout antagonistic to the fish pathogen Flavobacterium psychrophilum. Sci. Rep., 11(1): 1-11.

Terova, G.; Cattaneo, A.G.; Preziosa, E.; Bernardini, G. and Saroglia, M. (2011). Impact of acute stress on antimicrobial polypeptides mRNA copy number in several tissues of marine sea bass (Dicentrarchus labrax). BMC Immunol., 12.

Trevelyan, W.E.; Forrest, R.S. and Harrison, J.S. (1952). Determination of yeast carbohydrate with the anthrone reagent. Nature. 170: 626-627.

Tsutsui, S.; Okamoto, M.; Ono, M.; Suetake, H.; Kikuchi, K.; Nakamura, O.; Suzuki, Y. and Watanabe, T. (2011). A new type of lectin discovered in a fish, flathead (Platycephalus indicus), suggests an alternative functional role for mammalian plasma kallikrein. Glycobiology. 21(12):1580-1587.

Tsutsui, S.; Yamaguchi, M.; Hirasawa, A.; Nakamura, O. and Watanabe, T. (2009). Common skate (Raja kenojei) secretes pentraxin into the cutaneous secretion: the first skin mucus lectin in cartilaginous fish. J. Biochem., 146(2): 295-306.

Tyor, A. K. and Kumari, S. (2016). Biochemical characterization and antibacterial properties of fish skin mucus of fresh water fish, Hypophthalmichthys nobilis. Int. J. Pharm. Pharm., 8: 132-136.

Uthayakumar, V.; Ramasubramanian, V.; Senthilkumar, D.; Priyadarisini, V. B. and Harikrishnan, R. (2012). Biochemical characterization, antimicrobial and hemolytic studies on skin mucus of fresh water spiny eel Mastacembelus armatus. Asian Pac. J. Trop. Biomed., 2(2): S863-S869.

Valdenegro-Vega, V.A.; Crosbie, P.; Bridle, A.; Leef, M.; Wilson, R. and Nowak, B.F. (2014). Differentially expressed proteins in gill and skin mucus of Atlantic salmon (Salmo salar) affected by amoebic gill disease. Fish Shellfish Immunol., 40(1): 69-77.

Valero, Y.; Chaves-Pozo, E.; Meseguer, J.; Esteban, M.A. and Cuesta, A. (2013). Biological role of fish antimicrobial peptides. Antimicrobial peptides. 2: 31-60.

Van der Marel M.; Caspari, N.; Neuhaus, H.; Meyer, W.; Enss, M. L. and Steinhagen, D. (2010). Changes in skin mucus of common carp, Cyprinus carpio L., after exposure to water with a high bacterial load. J. Fish Dis., 33(5): 431-439. 
Vennila, R.; Kumar, K.R.; Kanchana, S.; Arumugam, M.; Vijayalakshmi, S. and Balasubramaniam, T. (2011). Preliminary investigation on antimicrobial and proteolytic property of the epidermal mucus secretion of marine stingrays. Asian Pac. J. Trop. Biomed. 1(2): S239-S243.

Wang, S.; Wang, Y.; Ma, J.; Ding, Y. and Zhang, S. (2011). Phosvitin plays a critical role in the immunity of zebrafish embryos via acting as a pattern recognition receptor and an antimicrobial effector. J. Biol. Chem., 286(25):22653-22664.

Williams, B.L. (2010). Behavioral and chemical ecology of marine organisms with respect to tetrodotoxin. Mar. Drugs., 8: 381-398.

Wisenden, B.D. and Barbour, K. (2005). Antipredator responses to skin extract of redbelly dace, Phoxinus eos, by free-ranging populations of redbelly dace and fathead minnows, Pimephales promelas. Environ. Biol. Fish., 72: 227-233.

Wu, M.; Maier, E.; Benz, R. and Hancock, R. E. (1999). Mechanism of interaction of different classes of cationic antimicrobial peptides with planar bilayers and with the cytoplasmic membrane of Escherichia coli. Biochem., 38(22): 7235-7242.

Zaccone, G.; Kapoor, B.G.; Fasulo, S. and Ainis, L. (2001). Structural, histochemical and functional aspects of the epidermis of fishes. Adv. Mar. Biol., 40: 253-348.

Zagarese, H. and Williamson, C.E. (2001). The implications of solar UV radiation exposure for fish and fisheries. Fish Fish (Oxf)., 2: 250-260.

Zamzow, J.P. (2004). Effects of diet, ultraviolet exposure and gender on the ultraviolet absorbance of fish mucus and ocular structures. Mar. Biol., 144: 1057-1064.

Zamzow, J.P. and Losey, G.S. (2002). Ultraviolet radiation absorbance by coral reef fish mucus: photo-protection and visual communication. Environ. Biol. Fish., 63: 41-47.

Zamzow, J. P. (2003). Ultraviolet-absorbing compounds in the mucus of temperate Pacific tidepool sculpins: variation over local and geographic scales. Mar. Ecol. Prog. Ser., 263: 169175. 